\title{
Customer Perception on Bank Service Quality: A Comparative Study between Conventional Commercial Banks and Islamic Commercial Banks in Bangladesh
}

\author{
Sonia Rezina ${ }^{1}$, Nur Ahmad ${ }^{2}$, Farhana Mitu ${ }^{3}$, Mohitul Ameen Ahmed Mustafi ${ }^{4^{*}}$ \\ ${ }^{1,4}$ Assistant Professor, School of Business (SoB), Uttara University, Dhaka, BANGLADESH \\ ${ }^{2}$ Senior Lecturer, Department of Business Administration, IBAIS University, Dhaka, BANGLADESH \\ ${ }^{3}$ Senior Lecturer, School of Business (SoB), Uttara University, Dhaka, BANGLADESH \\ *Corresponding Contact: \\ Email: mustafi559@gmail.com
}

\begin{abstract}
Customer perception refers to the process by which a customer selects, organizes, and interprets information inputs to create a meaningful picture of the service quality within an organization. In the fast growing banking industry like Bangladesh, every bank is looking forward towards faster growth through providing better service quality than others. However, there are certain challenges started rising in front of the booming banking sector which are needed to be addressed immediately; such as, managing compliance, mitigating fraud/ cyber security, managing hiring decisions etc. It is obvious that, those who will efficiently handle these challenges will certainly lead the market and gain higher customer contentment. The main purpose of this study is to compare the customer perception towards the service Quality offered by Conventional Commercial Banks and Islamic Shariah-based Commercial Banks in Bangladesh through using SERVQUAL instrument. 204 respondents have been randomly selected for the study among them 162 is from Conventional banks and 42 are from Islamic banks. The findings of the research should help the policy makers and regulators in banking industry to have a deep insight towards the different perception of customers and assist in taking effective measures to achieve organizational goal through improving their service Quality.
\end{abstract}

Key Words: Conventional Commercial Banks, Islamic Commercial Banks, Customer Perception, Service Quality

\section{INTRODUCTION}

The banking sector in Bangladesh plays an important role in the national economy of Bangladesh. In recent years, due to increase competition between public and private banks, 
the banking sector has faced remarkable change and bought huge revolution in customer perception on banking service in Bangladesh. It is necessary for every bank to regularly study the customer perception about the service, what new expectation about the service they have, and how they can be satisfied to retain the old customer and attract the new customers. In recent times the number of scheduled Commercial banks has been increased tremendously, as a result the nature of products and services being offered by the Bangladeshi banks have also been changed. Banks now have realized that delivery of good service quality is highly associated with customers' satisfaction, complaint reduction, bank preferences and brand loyalty (Reza et al, 2012) and bank selection by the customers' is also affected by the service quality (Rehman and Ahmed, 2008). Nowadays, better and quality service to customer becomes the main agenda of banks.

Customers are the most important stakeholders in service industries (Nguyen, 2012). Service quality is expected to be the difference between customer expectations and perceptions either it is acknowledged or being acknowledged by the customer (Parasuraman et al, 1988). Service quality can be defined as "the difference between customers' expectations for service performance preceding to the service encounter and their perceptions of the service expected" (Asubonteng et al., 1996). Due to the rising importance of service quality mainly in banking sector of Bangladesh, this study is focused on to estimate the variation of perception between Conventional Commercial Banks and Islamic Shariah-based Commercial Banks in Bangladesh. For this purpose, 'SERVQUAL' instrument was used to compute the customer perception about service quality delivered by these banks. Six service quality dimensions; tangibility, reliability, responsiveness, assurance, empathy and technology were used in order to determine the customers' perceptions about the service quality of the Conventional Commercial Banks and Islamic Shariah-based Commercial Banks located in Bangladesh.

The Bangladesh banking sector relative to the size of its economy is comparatively larger than many economies of similar level of development and per capita income (Asaduzzaman et al., 2012). Currently there are 56 scheduled banks which include 6 state-owned commercial banks, 2 specialized banks, 31 Domestic private commercial banks, 8 Islamic Shariah based commercial banks and 9 foreign-owned commercial banks in Bangladesh (Bangladesh Bank, 2016).

\section{LITERATURE REVIEW}

A large number of studies have been conducted on customer satisfaction of commercial banks in Bangladesh. According to Lewis and Boom (1983), "Service is a measure of how well the service level delivered matches customer expectations. Delivering quality service means conforming to customer expectation on a consistent basis." Due to unique features of service, it is difficult not only to measure service quality, but also to provide the same quality of services to all customers. (Parasuraman et al. 1988). Karatepe et al (2005) pointed out the importance of developing industry-specific measures of customer service quality. Their study revealed that interaction quality is the most important dimension of service quality followed by empathy, reliability and service environment.

In case of conducting research on customer satisfaction of the banking industry, many researchers have followed Parasuraman, Zeithaml and Berry's SERVQUAL model, whereas there are few researchers who applied new models and approaches while measuring customer service quality. For example, Kemal Avkiran (1994) developed a multi-dimensional instrument for measuring customer perceived quality in retail branch banking. He used 
SERVQUAL as a starting point and then emerged by adding new items like staff conduct, credibility, communication and access to banker services. Bahia and Nantel (2000) developed a reliable and valid scale for the measurement of the perceived service quality of bank services which span six dimensions: effectiveness and assurance; access; price; tangibles; services portfolio and reliability. Aldlaigan and Buttle (2002) described the development of a new scale designed to measure service quality perceptions of retail bank customers based on the technical and functional service quality schema proposed by Grönroos. Their study resulted in SYSTRA-SQ, which consists of four dimensions: service system quality, behavioral service quality, service transactional accuracy, and machine service quality.

Study conducted by Wakefield and Blodgett (1999) stated that the tangible physical environment plays an important role to influence customer perceptions and feelings towards service quality. Afrin (2012) found the Responsiveness as the most important dimension of overall bank service quality in Bangladesh followed by Tangibility, Reliability, Assurance and Empathy. Siddiqi (2011) found that there is a positive relationship between service quality attributes and customers' satisfaction in Bangladesh. The study was also supported by Ahmad and Anis et al. (2011) in their comparative study of Islamic and Conventional banks in Pakistan. Rahman et al (2011) found that organizations offering high service quality got competitive advantage over other similar firms. According to Asaduzzaman et al. (2012), recommendations should be given by marketing managers to initiate extensive customerrelations training program for stimulating the banks' core competency.

\section{Objective OF the Study}

The basic objective of the study is to identify the customer perception on bank service Quality in Conventional commercial banks and Islamic Shariah-based commercial banks in Bangladesh. Specific objectives are:

- To determine the influential factors those define the quality of customer service in both Conventional banks and Islamic banks in Bangladesh.

- To make a comparison of the customer perception of bank service in these two categories of banks.

\section{Methodology of the Study}

Among 39 Conventional commercial banks and 8 Islamic banks in Bangladesh, currently there are more than 10 lac customers who have regular transactions with these banks. This study is based on primary data. A structured questionnaire was designed to collect primary data by using literature review. The primary data were collected through personal interview while respondents were getting service in their respective banks.

To determine the sample size of customer, published formula of University of Florida was used as a reference. According to this table, the sample size for the more than 10 lac population size with $93 \%$ confidence level and $\pm 7 \%$ precision level are approximately 204 using the formula,

$\mathrm{n}=\frac{\mathrm{N}}{\left(1+\mathrm{Ne}^{2}\right)^{\prime}}$;

Where $\mathrm{n}$ is sample size, $\mathrm{N}$ is the population size, and e is the level of precision.

From these 204 samples, we have applied weighted average method to distribute the respondents in the following manner: 
Table 1: Application of Weighted Average Method for sampling

\begin{tabular}{|l|c|c|}
\hline Category of Bank & Total Bank & Weighted Average \\
\hline Islamic commercial banks & 8 & Sample $=\frac{8}{39} \times 204=42$ \\
\hline Conventional Commercial Banks & 31 & Sample $=\frac{31}{39} \times 204=162$ \\
\hline Total & 39 & 204 \\
\hline
\end{tabular}

After weighted average, we have applied simple random sampling technique for collecting data from the respective banks. Five point Likert scale ranging from 1 (strongly disagree) to 5 (strongly agree) was used to collect data from the respondents. Two demographic variables, namely, age, and gender were taken to determine the variability of six dimensions across those variables. For analysis of the demographic information, we used SPSS software. By using Smart PLS software, we have found the influential factors for both Conventional commercial\& Islamic banks and also comparison of those factors.

\section{HYPOTHESES TESTING}

Two hypothesis have been tested one is null hypothesis $\left(\mathrm{H}_{0}\right)$ and another is alternative hypothesis $\left(\mathrm{H}_{1}\right)$.

(For Conventional Commercial Bank)

- Null hypothesis: $\mathbf{H}_{0}=$ Customer Perception towards Overall service quality does not depend on Assurance, Empathy, Reliability, Responsiveness, Tangibility, Technology

- Alternative hypothesis: $\mathbf{H}_{1}=$ Customer Perception towards Overall service quality depends on Assurance, Empathy, Reliability, Responsiveness, Tangibility, Technology

(For Islamic Bank)

- Null hypothesis: $\mathbf{H}_{0}=$ Customer Perception towards Overall service quality does not depend on Assurance, Empathy, Reliability, Responsiveness, Tangibility, Technology

- Alternative hypothesis: $\mathbf{H}_{1}=$ Customer Perception towards Overall service quality depends on Assurance, Empathy, Reliability, Responsiveness, Tangibility, Technology

(For both Conventional Commercial and Islamic Bank)

- Null hypothesis: $\mathbf{H}_{\mathbf{0}}=$ Customer Perception towards Overall service quality does not depend on Assurance, Empathy, Reliability, Responsiveness, Tangibility, Technology

- Alternative hypothesis: $\mathbf{H}_{1}=$ Customer Perception towards Overall service quality depends on Assurance, Empathy, Reliability, Responsiveness, Tangibility, Technology

Statistical tools used: Both descriptive and inferential statistics were used to analyze the data. Inferential statistics like Factor Analysis (FA) was used to separate the factors related to overall bank service Quality of Conventional and Islamic banks in Bangladesh. Partial Least Square method was also used to identify the significant factors from the factors identified through factor analysis.

Convergent validity: When multiple items are used to measure an individual construct, the item (indicator) convergent validity should be one of the main concerns to the researcher. Anderson and Gerbing (1988) stated that convergent validity is established if all factor loadings for the items measuring the same construct are statistically significant. According to Hair et al. (1998) convergent validity could be accessed through factor loadings, composite reliability and the average variance extracted. The results of the measurement model in Table- 5, 6 and 7 show that the loadings for all items exceeded the recommended value of 0.50 (Hair et al. 1998).Composite reliability (CR) values ranged from 0.872 to 0.934 
for Conventional Banks, 0.785 to 0.958 for Islamic Bank, combined 0.944 to 0.831 which exceeded the recommended value of 0.70 (Hair et al. 1998).

Average variance extracted: All values of the average variance extracted (AVE) that measures the variance captured by the indicators relative to measurement error were greater than 0.50 to indicate acceptability of the constructs (Fornell \& Larcker, 1981; Henseler, Ringle, \& Sinkovics, 2009). It is seen that these indicators satisfied the convergent validity of the constructs (Table- $5,6,7$ ).

Test of Reliability: To analyze the reliability (internal consistency) of the variables, this study used the Cronbach's alpha coefficient and composite reliability (CR) value. Table 5, 6 and 7 shows all Cronbach's alpha values are above 0.60 cutoff values as suggested by Nunnally and Berstein (1994). Standardized Cronbach's alpha formula is given below.

$\alpha=\frac{N \cdot \bar{C}}{\bar{V}+(N-1) \cdot \bar{C}}$

Here, $\mathrm{N}$ is equal to the number of items, c-bar is the average inter-item covariance among the items and v-bar equals the average variance.

Coefficient of determination: The reliability also finds that the coefficient of determination $\mathrm{R}$ square (0.38) for Conventional banks, 0.732 for Islamic Bank, and 0.516 for both Conventional banks, Islamic Bank for the dependent variable i.e., overall bank service Quality of Conventional and Islamic banks in Bangladesh. This means that the only six independent variables are moderately explain $51.6 \%$ of the variance in both Conventional banks, Islamic Bank for the dependent variable.

\section{VALIDITY AND RELIABILITY ANALYSES FOR THE INSTRUMENT}

Table-2: Discriminant Analysis

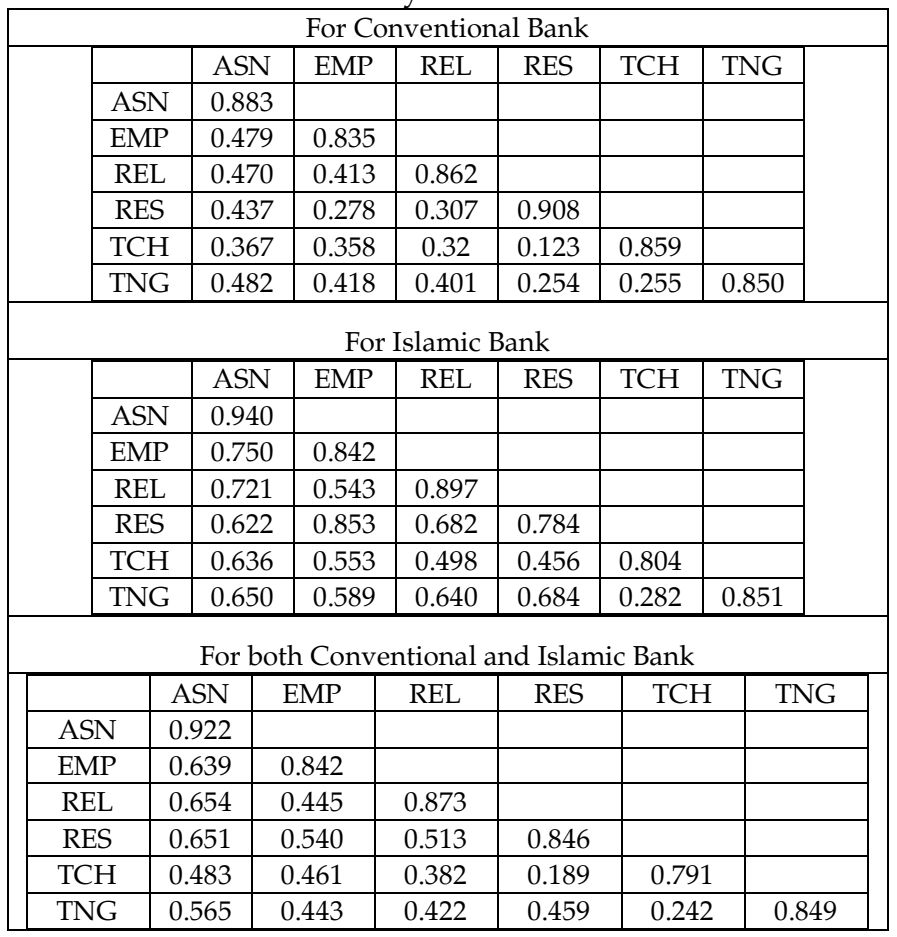


Table 2 shows the results of convergent and discriminant validity analyses. All constructs had the values of average variance extracted (AVE) larger than 0.5 indicating that they met the acceptable standard of convergent validity (Barclay, Higgins \& Thompson, 1995; Fornell \& Larcker, 1981; Henseler et al., 2009). Besides that, all constructs had the values of AVE square root in diagonal were greater than the squared correlation with other constructs in off diagonal, showing that all constructs met the acceptable standard of discriminant validity (Henseler et al., 2009). From the below table we have concluded that all factors value were higher than 0.50 in the Discriminants table.

\section{RESULTS AND FINDINGS}

Table 3: Demographic information of both Conventional Bank and Islamic Bank in Bangladesh

\begin{tabular}{|c|c|c|c|c|c|c|c|}
\hline & \multicolumn{3}{|c|}{ Conventional Bank } & \multicolumn{2}{c|}{ Islamic Bank } & \multicolumn{2}{c|}{$\begin{array}{c}\text { Both Conventional Bank } \\
\text { and Islamic Bank }\end{array}$} \\
\hline & & Frequency & Percent & Frequency & Percent & Frequency & Percent \\
\hline \multirow{3}{*}{ Gender } & Male & 80 & 49.7 & 32 & 78.0 & 112 & 55.4 \\
\cline { 2 - 8 } & Female & 82 & 50.3 & 10 & 22.0 & 92 & 44.6 \\
\cline { 2 - 8 } & Total & 162 & 100.0 & 42 & 100.0 & 204 & 100.0 \\
\hline $\begin{array}{c}\text { Age of the } \\
\text { respondents }\end{array}$ & $18-30$ years & 90 & 55.9 & 18 & 43.9 & 108 & 53.5 \\
\cline { 2 - 8 } & $31-45$ years & 63 & 39.1 & 18 & 43.9 & 81 & 40.1 \\
\cline { 2 - 8 } & $\begin{array}{c}45 \text { years } \\
\text { and above }\end{array}$ & 9 & 5.0 & 6 & 12.2 & 115 & 6.4 \\
\cline { 2 - 8 } & Total & 162 & 100.0 & 42 & 100.0 & 204 & 100.0 \\
\hline
\end{tabular}

Table-3 provides the frequency distribution of the gender comprised of male and female. A total of 162 respondents in Conventional commercial banks were included in this study, out of which 80 respondents were male representing $49.7 \%$ of the total population and remaining 81 respondents were female representing $50.3 \%$ of the total population. A total of 42 respondents in Islamic commercial banks were included in this study, out of which 32 respondents were male representing $78 \%$ of the total population and remaining 10 respondents were female representing $22 \%$ of the total population. Hence, 204 respondents were reached in total from both Conventional and Islamic banks, among them 112 respondents were male representing $55.4 \%$ of the total population and 92 respondents were female representing $44.6 \%$ of the total population.

Table- 3 also provides the frequency distribution of the age of the respondents. A total of 161 respondents in Conventional commercial banks were included in this study, out of which 90 respondents were having age of $18-30$ years representing $55.9 \%$ of the total population, 63 respondents were having age of $31-45$ years representing $39.1 \%$ of the total population and remaining 9 respondents were having age above 45 years representing $5 \%$ of the total population. A total of 41 respondents in Islamic commercial banks were included in this study, out of which 18 respondents were having age of $18-30$ years representing $43.9 \%$ of the total population, 18 respondents were having age of $31-45$ years representing $43.9 \%$ of the total populationand remaining 6 respondents were having age above 45 years representing $12.2 \%$ of the total population. Hence, 202 respondents were reached in total from both Conventional and Islamic banks, among them 108 respondents were having age of $18-30$ years representing $53.5 \%$ of the total population, 81 respondents were having age of 31-45 years representing $40.1 \%$ of the total population and remaining 15 respondents were having age above 45 years representing $6.4 \%$ of the total population. 
Table 4: Factor Analysis (For Conventional Bank)

\begin{tabular}{|c|c|c|c|c|c|c|c|}
\hline Factors & & $\begin{array}{l}\text { Factor } \\
\text { Loading }\end{array}$ & \begin{tabular}{|c|}
$\mathrm{T}-$ \\
value
\end{tabular} & $\begin{array}{c}\text { Cronbach's } \\
\text { Alfa }\end{array}$ & \begin{tabular}{|l|} 
Composite \\
Reliability
\end{tabular} & AVE & VIF \\
\hline \multirow[t]{3}{*}{ Assurance } & $\begin{array}{c}\text { Strong knowledge to } \\
\text { answer enquiries }\end{array}$ & 0.929 & 39.095 & \multirow{3}{*}{0.858} & \multirow{3}{*}{0.914} & \multirow{3}{*}{0.780} & \multirow{3}{*}{1.928} \\
\hline & $\begin{array}{l}\text { Employees are polite } \\
\text { and helpful }\end{array}$ & 0.873 & 25.464 & & & & \\
\hline & $\begin{array}{c}\text { Efficient and fast in } \\
\text { service delivery }\end{array}$ & 0.845 & 19.503 & & & & \\
\hline \multirow[t]{3}{*}{ Empathy } & $\begin{array}{l}\text { Staffs enthusiasm to } \\
\text { understand customer } \\
\text { need }\end{array}$ & 0.933 & 42.032 & \multirow[t]{3}{*}{0.785} & \multirow[t]{3}{*}{0.872} & \multirow[t]{3}{*}{0.697} & \multirow[t]{3}{*}{1.764} \\
\hline & $\begin{array}{c}\text { Provides convenient } \\
\text { service charges }\end{array}$ & 0.865 & 16.344 & & & & \\
\hline & $\begin{array}{c}\text { Bank always informs } \\
\text { about new and } \\
\text { attractive offers }\end{array}$ & 0.687 & 5.620 & & & & \\
\hline \multirow[t]{3}{*}{ Reliability } & $\begin{array}{c}\text { Safety with all } \\
\text { transactions }\end{array}$ & 0.900 & 12.671 & \multirow[t]{3}{*}{0.831} & \multirow[t]{3}{*}{0.896} & \multirow[t]{3}{*}{0.742} & \multirow[t]{3}{*}{1.495} \\
\hline & $\begin{array}{c}\text { Keeps its records } \\
\text { accurately }\end{array}$ & 0.867 & 13.272 & & & & \\
\hline & Promised deadlines & 0.815 & 11.546 & & & & \\
\hline \multirow[t]{3}{*}{ Responsibility } & $\begin{array}{c}\text { Fast and efficient } \\
\text { counter services }\end{array}$ & 0.907 & 34.679 & \multirow{3}{*}{0.894} & \multirow{3}{*}{0.934} & \multirow{3}{*}{0.825} & \multirow{3}{*}{1.266} \\
\hline & $\begin{array}{c}\text { Regular and effective } \\
\text { complaint handling } \\
\text { process }\end{array}$ & 0.918 & 42.537 & & & & \\
\hline & $\begin{array}{l}\text { The employee help in } \\
\text { solving the problems }\end{array}$ & 0.899 & 31.749 & & & & \\
\hline \multirow[t]{3}{*}{ Technology } & $\begin{array}{c}\text { No difficulties with } \\
\text { bank cards }\end{array}$ & 0.933 & 48.909 & \multirow{3}{*}{0.831} & \multirow{3}{*}{0.893} & \multirow{3}{*}{0.738} & \multirow{3}{*}{1.502} \\
\hline & $\begin{array}{l}\text { ATM service and the } \\
\text { machines are installed } \\
\text { at proper locations }\end{array}$ & 0.888 & 16.265 & & & & \\
\hline & $\begin{array}{c}\text { Bank offers internet } \\
\text { banking services }\end{array}$ & 0.745 & 6.807 & & & & \\
\hline \multirow[t]{3}{*}{ Tangibility } & $\begin{array}{c}\text { Suitably dressed and } \\
\text { have neat \& clean } \\
\text { Appearance }\end{array}$ & 0.881 & 16.216 & \multirow{3}{*}{0.807} & \multirow{3}{*}{0.886} & \multirow{3}{*}{0.723} & \multirow{3}{*}{1.379} \\
\hline & $\begin{array}{c}\text { Necessary modern } \\
\text { equipment }\end{array}$ & 0.876 & 13.736 & & & & \\
\hline & $\begin{array}{l}\text { Proper waiting and } \\
\text { sitting arrangements }\end{array}$ & 0.790 & 10.301 & & & & \\
\hline
\end{tabular}


Table 4 shows the factor loadings and cross loadings for different constructs. The correlation between items and factors had higher loadings than other items in the different constructs. The loadings of variables more strongly on their own constructs in the model, greater than 0.7 are considered adequate (Chin, 1998; Fornell \& Larcker, 1981; Gefen \& Straub, 2005; Henseler et al., 2009). In sum, the validity of measurement model meets the criteria.

Table 5 shows the results of reliability analysis for the instrument. The composite reliability and Cronbach's Alpha had values of greater than 0.8, indicating that the measurement scale used in this study had high internal consistency (Henseler et al., 2009; Nunally \& Benstein, 1994; Sekaran \& Bougie, 2010).

Generally, a global fit measure (GOF) was conducted for path modeling, it is defined as the geometric mean of average communality and average $R^{2}$ (especially endogenous variables) (Chin, 2010) (see the formula).In this study, GOF value was $0.53\left(R^{2}=0.380\right.$, average AVE $=$ 0.750 for customer perception on bank service Quality). So, the value of GOF exceeded the largest cut-off value (0.36) and it was indicated that the proposed model of this study had better explaining power than that based on the recommended value of $\mathrm{GOF}_{\text {small }}=0.1$, $\mathrm{GOF}_{\text {medium }}=0.25$, and $\mathrm{GOF}_{\text {large }}=0.36$ (Akter et al., 2011).

$\mathrm{GOF}=\sqrt{A V E \times R^{2}}$

From table-4 also shows that, all of the T-Statistic is larger than 1.96 at 5\% level of significance, we can say that the outer model loadings are highly significant. So, our model is accepted for above evidence in this study.

Table 5 shows the factor loadings and cross loadings for different constructs. The correlation between items and factors had higher loadings than other items in the different constructs. The loadings of variables more strongly on their own constructs in the model, greater than 0.7 are considered adequate (Chin, 1998; Fornell \& Larcker, 1981; Gefen \& Straub, 2005; Henseler et al., 2009). In sum, the validity of measurement model meets the criteria.

Table 6 shows the results of reliability analysis for the instrument. The composite reliability and Cronbach's Alpha had values of greater than 0.8, indicating that the measurement scale used in this study had high internal consistency (Henseler, Ringle \& Sinkovics, 2009; Nunally \& Benstein, 1994; Sekaran \& Bougie, 2010). 
Table 5: Factor Analysis (For Islamic Bank)

\begin{tabular}{|c|c|c|c|c|c|c|c|}
\hline Factors & & $\begin{array}{l}\text { Factor } \\
\text { Loading }\end{array}$ & $\begin{array}{c}\text { T- } \\
\text { value }\end{array}$ & $\begin{array}{l}\text { Cronbach's } \\
\text { Alfa }\end{array}$ & $\begin{array}{l}\text { Composite } \\
\text { Reliability }\end{array}$ & AVE & VIF \\
\hline \multirow[t]{3}{*}{ Assurance } & $\begin{array}{l}\text { Strong knowledge to } \\
\text { answer enquiries }\end{array}$ & 0.962 & 63.743 & \multirow{3}{*}{0.934} & \multirow{3}{*}{0.958} & \multirow{3}{*}{0.884} & \multirow{3}{*}{2.75} \\
\hline & $\begin{array}{c}\text { Efficient and fast in service } \\
\text { delivery }\end{array}$ & 0.943 & 44.560 & & & & \\
\hline & $\begin{array}{c}\text { Employees are polite and } \\
\text { helpful }\end{array}$ & 0.914 & 28.483 & & & & \\
\hline \multirow[t]{3}{*}{ Empathy } & $\begin{array}{c}\text { Provides convenient } \\
\text { service charges }\end{array}$ & 0.942 & 39.759 & \multirow{3}{*}{0.833} & \multirow{3}{*}{0.879} & \multirow{3}{*}{0.709} & \multirow{3}{*}{2.50} \\
\hline & $\begin{array}{l}\text { Bank always informs abou } \\
\text { new and attractive offers }\end{array}$ & 0.836 & 5.836 & & & & \\
\hline & $\begin{array}{l}\text { Staffs enthusiasm to } \\
\text { understand customer } \\
\text { needs }\end{array}$ & 0.736 & 3.452 & & & & \\
\hline \multirow[t]{3}{*}{ Reliability } & $\begin{array}{c}\text { Keeps its records } \\
\text { accurately }\end{array}$ & 0.965 & 122.29 & \multirow{3}{*}{0.876} & \multirow{3}{*}{0.924} & \multirow{3}{*}{0.804} & \multirow{3}{*}{2.61} \\
\hline & Safety with all transactions & 0.902 & 20.545 & & & & \\
\hline & Promised deadlines & 0.816 & 6.504 & & & & \\
\hline \multirow[t]{3}{*}{ Responsibility } & $\begin{array}{c}\text { Regular and effective } \\
\text { complaint handling } \\
\text { process }\end{array}$ & 0.856 & 18.067 & \multirow{3}{*}{0.710} & \multirow{3}{*}{0.825} & \multirow{3}{*}{0.615} & \multirow{3}{*}{2.44} \\
\hline & $\begin{array}{c}\text { Fast and efficient counter } \\
\text { services }\end{array}$ & 0.838 & 14.632 & & & & \\
\hline & $\begin{array}{c}\text { Employees help in solving } \\
\text { the problems }\end{array}$ & 0.641 & 3.311 & & & & \\
\hline \multirow[b]{2}{*}{ Technology } & Internet banking services & 0.839 & 19.097 & \multirow[b]{2}{*}{0.700} & \multirow[b]{2}{*}{0.785} & \multirow[b]{2}{*}{0.647} & \multirow[b]{2}{*}{2.11} \\
\hline & $\begin{array}{c}\text { No difficulties with bank } \\
\text { cards }\end{array}$ & 0.768 & 7.639 & & & & \\
\hline \multirow[t]{3}{*}{ Tangibility } & $\begin{array}{c}\text { Proper waiting and sitting } \\
\text { arrangements }\end{array}$ & 0.901 & 5.613 & \multirow{3}{*}{0.819} & \multirow{3}{*}{0.887} & \multirow{3}{*}{0.725} & \multirow{3}{*}{2.27} \\
\hline & $\begin{array}{c}\text { Necessary modern } \\
\text { equipment }\end{array}$ & 0.852 & 6.514 & & & & \\
\hline & $\begin{array}{c}\text { Suitably dressed and neat } \\
\text { and clean appearance of } \\
\text { employees }\end{array}$ & 0.798 & 4.136 & & & & \\
\hline
\end{tabular}

Generally, a global fit measure (GOF) was conducted for path modeling, it is defined as the geometric mean of average communality and average $R^{2}$ (especially endogenous variables) (Chin, 2010) (see the formula).In this study, GOF value was $0.73\left(R^{2}=0.73\right.$, average AVE $=$ 0.73 for customer perception on bank service Quality). So, the value of GOF exceeded the largest cut-off value (0.36) and it was indicated that the proposed model of this study had better explaining power than that based on the recommended value of $\mathrm{GOF}_{\text {small }}=0.1$, $\mathrm{GOF}_{\text {medium }}=0.25$, and $\mathrm{GOF}_{\text {large }}=0.36$ (Akter et al., 2011).

$\mathrm{GOF}=\sqrt{A V E \times R^{2}}$

From table-5 also shows that, all of the T-Statistic is larger than 1.96 at $5 \%$ level of significance, we can say that the outer model loadings are highly significant. So, our SEM model is accepted for above evidence in this study.0.613743 
Table 6: Factor Analysis (Both Conventional and Islamic Bank)

\begin{tabular}{|c|c|c|c|c|c|c|c|}
\hline Factors & Variables & $\begin{array}{c}\text { Factor } \\
\text { Loading }\end{array}$ & $\begin{array}{c}\text { T- } \\
\text { Value }\end{array}$ & $\begin{array}{l}\text { Cronbach's } \\
\text { Alfa }\end{array}$ & $\begin{array}{l}\text { Composite } \\
\text { Reliability }\end{array}$ & AVE & VIF \\
\hline \multirow[t]{3}{*}{ Assurance } & $\begin{array}{c}\text { Strong knowledge to answer } \\
\text { enquiries }\end{array}$ & 0.949 & 78.897 & \multirow{3}{*}{0.911} & \multirow{3}{*}{0.944} & \multirow{3}{*}{0.849} & \multirow{3}{*}{2.922} \\
\hline & $\begin{array}{c}\text { Efficient and fast in service } \\
\text { delivery }\end{array}$ & 0.920 & 42.221 & & & & \\
\hline & $\begin{array}{l}\text { Employees are polite } \\
\text { and helpful }\end{array}$ & 0.895 & 34.169 & & & & \\
\hline \multirow[t]{3}{*}{ Empathy } & $\begin{array}{c}\text { Bank provides convenient } \\
\text { service charges }\end{array}$ & 0.888 & 23.992 & \multirow[b]{3}{*}{0.805} & \multirow[b]{3}{*}{0.879} & \multirow[b]{3}{*}{0.708} & \multirow[b]{3}{*}{1.958} \\
\hline & $\begin{array}{l}\text { Staffs have the enthusiasm to } \\
\text { understand customer needs }\end{array}$ & 0.837 & 8.768 & & & & \\
\hline & $\begin{array}{c}\text { Bank always informs about } \\
\text { new and } \\
\text { attractive offers }\end{array}$ & 0.796 & 8.277 & & & & \\
\hline \multirow[t]{3}{*}{ Reliability } & $\begin{array}{c}\text { Bank keeps its records } \\
\text { accurately }\end{array}$ & 0.920 & 36.743 & \multirow{3}{*}{0.843} & \multirow{3}{*}{0.906} & \multirow{3}{*}{0.762} & \multirow{3}{*}{1.793} \\
\hline & Safety with all transactions & 0.877 & 27.913 & & & & \\
\hline & Promised deadlines & 0.819 & 12.580 & & & & \\
\hline \multirow[t]{3}{*}{ Responsibility } & $\begin{array}{c}\text { Regular and effective } \\
\text { complaint handling } \\
\text { process }\end{array}$ & 0.891 & 35.455 & \multirow{3}{*}{0.812} & \multirow{3}{*}{0.883} & \multirow{3}{*}{0.715} & \multirow{3}{*}{2.037} \\
\hline & $\begin{array}{c}\text { Fast and efficient counter } \\
\text { services }\end{array}$ & 0.833 & 19.174 & & & & \\
\hline & $\begin{array}{c}\text { The employee help in solving } \\
\text { the problems }\end{array}$ & 0.811 & 9.626 & & & & \\
\hline \multirow[t]{3}{*}{ Technology } & $\begin{array}{l}\text { No difficulties with } \\
\text { bank cards }\end{array}$ & 0.893 & 11.347 & \multirow[t]{3}{*}{0.719} & \multirow[t]{3}{*}{0.831} & \multirow[t]{3}{*}{0.625} & \multirow[t]{3}{*}{1.490} \\
\hline & Internet banking services & 0.796 & 9.381 & & & & \\
\hline & $\begin{array}{l}\text { ATM service and the } \\
\text { machines are installed } \\
\text { at proper locations }\end{array}$ & 0.666 & 3.778 & & & & \\
\hline \multirow[t]{3}{*}{ Tangibility } & $\begin{array}{c}\text { Proper waiting and sitting } \\
\text { arrangements }\end{array}$ & 0.855 & 14.248 & \multirow{3}{*}{0.808} & \multirow{3}{*}{0.886} & \multirow{3}{*}{0.721} & \multirow{3}{*}{1.570} \\
\hline & $\begin{array}{c}\text { Necessary modern } \\
\text { equipment }\end{array}$ & 0.848 & 14.228 & & & & \\
\hline & $\begin{array}{c}\text { Suitably dressed and neat } \\
\text { and clean appearance of } \\
\text { employees }\end{array}$ & 0.844 & 12.278 & & & & \\
\hline
\end{tabular}

Table 6 shows the factor loadings and cross loadings for different constructs. The correlation between items and factors had higher loadings than other items in the different constructs. The loadings of variables more strongly on their own constructs in the model, greater than 0.7 are considered adequate (Chin, 1998; Fornell \& Larcker, 1981; Gefen \& Straub, 2005; Henseler et al., 2009). In sum, the validity of measurement model meets the criteria.

Table 7 shows the results of reliability analysis for the instrument. The composite reliability and Cronbach's Alpha had values of greater than 0.719, indicating that the measurement scale used in this study had high internal consistency (Henseler, Ringle \& Sinkovics, 2009; Nunally \& Benstein, 1994; Sekaran \& Bougie, 2010). 
Generally, a global fit measure (GOF) was conducted for path modeling, it is defined as the geometric mean of average communality and average $R^{2}$ (especially endogenous variables) (Chin, 2010) (see the formula).In this study, GOF value was $0.61\left(R^{2}=0.516\right.$, average AVE $=$ 0.73 for customer perception on bank service Quality). So, the value of GOF exceeded the largest cut-off value (0.36) and it was indicated that the proposed model of this study had better explaining power than that based on the recommended value of GOF small $=0.1$, GOF medium $=0.25$, and GOF large $=0.36$ (Akter et al., 2011).

\section{$\mathrm{GOF}=\sqrt{A V E \times R^{2}}$}

From table-6 also shows that, all of the T-Statistic is larger than 1.96 at 5\% level of significance, we can say that the outer model loadings are highly significant. So, our SEM model is accepted for above evidence in this study.

\section{Outcomes of Testing Direct Effects Model}

Table 7: Path Analysis (Conventional Banks)

\begin{tabular}{|c|c|c|c|c|c|}
\hline & $\begin{array}{c}\text { Original } \\
\text { Sample }\end{array}$ & $\begin{array}{c}\text { Sample } \\
\text { Mean }\end{array}$ & $\begin{array}{c}\text { Standard } \\
\text { Deviation }\end{array}$ & $\begin{array}{c}\text { T- } \\
\text { Value }\end{array}$ & $\begin{array}{c}\text { P- } \\
\text { Value }\end{array}$ \\
\hline ASN- OS & 0.136 & 0.119 & 0.121 & 1.124 & 0.261 \\
\hline EMP- OS & 0.092 & 0.073 & 0.118 & 0.781 & 0.435 \\
\hline REL- OS & -0.002 & 0.005 & 0.118 & 0.015 & 0.988 \\
\hline RES- OS & 0.290 & 0.302 & 0.092 & 3.147 & 0.002 \\
\hline TCH- OS & 0.178 & 0.192 & 0.100 & 1.768 & 0.078 \\
\hline TNG-OS & 0.201 & 0.215 & 0.109 & 1.834 & 0.067 \\
\hline R-Square & \multicolumn{5}{|l}{0.380} \\
\hline R-Square Adjusted & \multicolumn{7}{|l|}{0.338} \\
\hline
\end{tabular}

Table 8: Path Analysis (Islamic Banks)

\begin{tabular}{|c|c|c|c|c|c|}
\hline & $\begin{array}{c}\text { Original } \\
\text { Sample }\end{array}$ & $\begin{array}{c}\text { Sample } \\
\text { Mean }\end{array}$ & $\begin{array}{c}\text { Standard } \\
\text { Deviation }\end{array}$ & $\begin{array}{c}\text { T- } \\
\text { Value }\end{array}$ & $\begin{array}{c}\text { P- } \\
\text { Value }\end{array}$ \\
\hline ASN- OS & 0.142 & 0.148 & 0.258 & 0.549 & 0.583 \\
\hline EMP-OS & -0.324 & -0.289 & 0.296 & 1.096 & 0.274 \\
\hline REL- OS & -0.20 & 0.232 & 0.171 & 1.168 & 0.243 \\
\hline RES-OS & -0.703 & 0.617 & 0.243 & 2.891 & 0.004 \\
\hline TCH- OS & 0.404 & 0.415 & 0.132 & 3.052 & 0.002 \\
\hline TNG-OS & -0.219 & -0.189 & 0.197 & 1.112 & 0.264 \\
\hline R-Square & \multicolumn{5}{|c|}{0.732} \\
\hline R-Square Adjusted & \multicolumn{7}{|c|}{0.685} \\
\hline
\end{tabular}

ASN=Assurance, EMP=Empathy, REL=Reliability, RES=Responsiveness, $\mathrm{TCH}=$ Technology, $\mathrm{TNG}=$ Tangibility, $\mathrm{OS}=$ Overall Satisfaction

Table 7 shows the outcomes of direct effect model consist of $\mathrm{H} 1$ and $\mathrm{H} 2$ for Conventional commercial banks. Firstly, Responsiveness highly significantly related with overall customers satisfaction of Conventional banks in Bangladesh $(\beta=0.29 ; t=3.147)$, therefore H0 was supported for Empathy, Assurance, Reliability, Technology and Tangibility. On the other hand H1 was supported for Responsiveness because their t-value were not higher than 1.96 at $5 \%$ level of significance. In sum, this result demonstrates that responsiveness act as important determinants of overall customer's satisfaction of Conventional commercial banks in Bangladesh.

Table 8 shows the outcomes of direct effect model consist of $\mathrm{H} 1$ and $\mathrm{H} 2$ for Islamic commercial banks. Responsiveness and Technology were highly significantly related with overall customers satisfaction of Islamic Banks in Bangladesh $(\beta=-0.703 ; t=2.891)$ and $(\beta=-$ $0.404 ; \mathrm{t}=3.052)$, therefore H0 was not supported for Assurance, Empathy, Reliability, and 
Tangibility. On the other hand H1 was supported for Responsiveness and Technology because their $\mathrm{t}$-value were not higher than 1.96 at $5 \%$ level of significance. In sum, this result demonstrates that responsiveness and Technology act as important determinants of overall customer satisfaction of Islamic Banks in Bangladesh.

Table-9: Path Analysis (both Conventional and Islamic Banks)

\begin{tabular}{|c|c|c|c|c|c|}
\hline & $\begin{array}{c}\text { Original } \\
\text { Sample }\end{array}$ & $\begin{array}{c}\text { Sample } \\
\text { Mean }\end{array}$ & $\begin{array}{c}\text { Standard } \\
\text { Deviation }\end{array}$ & $\begin{array}{c}\text { T- } \\
\text { Value }\end{array}$ & $\begin{array}{c}\text { P- } \\
\text { Value }\end{array}$ \\
\hline ASN- OS & 0.380 & 0.346 & 0.130 & 2.930 & 0.004 \\
\hline EMP- OS & -0.061 & 0.055 & 1.47 & 0.417 & 0.677 \\
\hline REL- OS & 0.346 & 0.367 & 0.100 & 3.452 & 0.001 \\
\hline RES- OS & 0.038 & 0.036 & 0.109 & 0.354 & 0.723 \\
\hline TCH- OS & 0.114 & 0.131 & 0.085 & 0.1334 & 0.183 \\
\hline TNG-OS & 0.029 & 0.039 & 0.108 & 0.272 & 0.786 \\
\hline R-Square & \multicolumn{5}{|c|}{0.516} \\
\hline R-Square Adjusted & \multicolumn{7}{|c|}{0.483} \\
\hline
\end{tabular}

ASN=Assurance, EMP=Empathy, REL=Reliability, RES=Responsiveness, $\mathrm{TCH}=$ Technology, TNG=Tangibility, OS=Overall Satisfaction

Table 9 shows the outcomes of direct effect model consist of $\mathrm{H} 1$ and $\mathrm{H} 2$ for both Conventional commercial banks and Islamic banks. Assurance and Reliability are highly significantly related with overall customers satisfaction of both Conventional and Islamic bank in Bangladesh $(\beta=$ $0.38 ; \mathrm{t}=2.93)$ and $(\beta=0.346 ; \mathrm{t}=3.452)$, therefore $\mathrm{H} 0$ was not supported for Empathy, Responsiveness, Technology and tangibility. On the other hand H1 was supported for Assurance and reliability because their t-value were not higher than 1.96 at $5 \%$ level of significance. In sum, this result demonstrates that reliability and assurance act as important determinants of overall customer satisfaction of both Conventional and Islamic bank in Bangladesh.

Table 10: Combined and bank wise level value path co-efficiency

\begin{tabular}{|c|c|c|c|}
\hline & Combined & Islamic & Conventional \\
\hline ASN & $0.380^{* * *}$ & 0.142 & 0.136 \\
\hline EMP & -0.061 & 0.289 & 0.092 \\
\hline REL & $0.346^{* * *}$ & 0.232 & -0.002 \\
\hline RES & 0.038 & $0.617^{* * *}$ & $0.290^{* * *}$ \\
\hline TCH & 0.114 & $0.415^{* * *}$ & 0.178 \\
\hline TNG & 0.029 & -0.189 & 0.201 \\
\hline
\end{tabular}

$* * * \mathrm{P} \leq 0.01,{ }^{* *} \mathrm{P} \leq 0.05,{ }^{*} \mathrm{P} \leq 0.10$

From Table-10 It is seen that, for Conventional banks, customer perception is stronger on Responsiveness from the bank employees regarding service delivery. Whereas, in case of Islamic banks, Responsiveness as well as Technology are the two important factors that contribute towards customer perception strongly. Hence, when we observed the two banks jointly, Assurance and Reliability stands as the strongest factors that affect the bank customer perception significantly.

\section{CONCLUSION}

Customer perception is a vital factor for the banking sector of a country. As bank is a service oriented sector, its prime focus should be delivering quality services so that customers' perception toward the bank service Quality improves. The main purpose of the study was to find out customers' perception on different aspects of Conventional commercial banks and Islamic banks in Bangladesh. There is no evidence of any research so far related to the above 
issue which focused on the comparative analysis on customer perception between Conventional commercial banks and Islamic Shariah-based banks in Bangladesh. The findings of the research should help the concerned authority to increase their service quality, and remove their lacking in the necessary areas. Banks must take more initiatives to provide advanced services to their customers and develop their perceptions towards bank service Quality.

\section{REFERENCES}

Afrin, T., 2012. Quality os Customer Service in the Banking Sector of Bangladesh: an explorative study.

Ahmad, A. and Safwan, N., 2011. Comparative study of Islamic and Conventional banking in Pakistan based on customer satisfaction. African Journal of Business Management, 5(5), p.1768.

Akter, K., Lanza, E. A., Martin, S. A., Myronyuk, N., Rua, M., \& Raffa, R. B. (2011). Diabetes mellitus and Alzheimer's disease: shared pathology and treatment?. British journal of clinical pharmacology, 71(3), 365-376.

Aldlaigan, A.H. and Buttle, F.A., 2002. SYSTRA-SQ: a new measure of bank service quality. International Journal of Service Industry Management, 13(4), pp.362-381.

Anis, A., Nasir, A., \& Safwan, N. (2011). Employee retention relationship to training and development: A compensation perspective. African journal of business management, 5(7), 2679.

Ashaduzzaman, M., Khan, M.M. and Farhana, S., 2012. User satisfaction review of Conventional commercial banks in Bangladesh.

Asubonteng, P., McCleary, K.J. and Swan, J.E. (1996).SERVQUAL revisited: A critical review of service quality, Journal of Services Marketing, Vol. 10 No. 6, pp. 62-81

Bahia, K. and Nantel, J., 2000. A reliable and valid measurement scale for the perceived service quality of banks. International journal of bank marketing, 18(2), pp.84-91.

Bangladesh Bank, 2016. Financial System. [Online] Available at: https:/ /www.bb.org.bd/fnansys/bankfi.php

Barclay, D., Higgins, C. and Thompson, R., 1995. The partial least squares (PLS) approach to causal modeling: Personal computer adoption and use as an illustration. Technology studies, 2(2), pp.285-309.

Chin, W. W. (2010). How to write up and report PLS analyses. In Handbook of partial least squares (pp. 655-690). Springer Berlin Heidelberg.

Chin, W.W., 1998. The partial least squares approach to structural equation modeling. Modern methods for business research, 295(2), pp.295-336.

Eidleman, Gregory J. (1995-02-01). "Z-Scores - A Guide to Failure Prediction". The CPA Journal Online.

Fornell, C. and Larcker, D.F., 1981. Evaluating structural equation models with unobservable variables and measurement error. Journal of marketing research, pp.39-50.

Gefen, D. and Straub, D., 2005. A practical guide to factorial validity using PLS-Graph: Tutorial and annotated example. Communications of the Association for Information systems, 16(1), p.5.

Gerbing, D.W. and Anderson, J.C., 1988. An updated paradigm for scale development incorporating unidimensionality and its assessment. Journal of marketing research, pp.186-192.

Hair, J. F., Anderson, R. E., Tatham, R. L., \& Black, W. C. (1998).Multivariate Data Analysis with Readings, $5^{\text {th }}$ Edition. Macmillan, New York.

Henseler, J., Ringle, C.M. and Sinkovics, R.R., 2009. The use of partial least squares path modeling in international marketing. Advances in international marketing, 20(1), pp.277-319.

Karatepe, O.M., Yavas, U. and Babakus, E., 2005. Measuring service quality of banks: Scale development and validation. Journal of Retailing and Consumer Services, 12(5), pp.373-383.

Kemal Avkiran, N., 1994. Developing an instrument to measure customer service quality in branch banking. International journal of bank marketing, 12 (6), pp.10-18. 
Lewis, R.C. and Booms, B.H., 1983. The marketing aspects of service quality. Emerging perspectives on services marketing, 65(4), pp.99-107.

Nguyen, M.T., 2012. Effects of service quality and price fairness on student satisfaction. International Journal of Business and Social Science, 3(19), pp. 132-150

Nunnally, J.C. and Bernstein, I.H., 1994. The assessment of reliability.Psychometric theory, 3(1), pp.248-292.

Parasuraman, A., Zeithaml, V.A. and Berry, L.L., 1988. SERVQUAL: a multiple-item scale for measuring consumer perceptions of service quality. Journal of retailing, 64(1), pp.12-40.

Rahaman, M.M., Abdullah, M. and Rahman, A., 2011. Measuring service quality using SERVQUAL model: A study on PCBs (Conventional Commercial Banks) in Bangladesh. Business Management Dynamics, 1(1), pp.1-11.

Raza, Shaukat Ali, et al. "Investigating service quality initiatives of Pakistani commercial banks." International business research 5.3 (2012): 107.

Rehman, H.U. and Ahmed, S., 2008. An empirical analysis of the determinants of bank selection in Pakistan: A customer view. Pakistan Economic and Social Review, pp.147-160.

Sekaran, U. and Bougie, R., 2010. Research Method for Business, A Skill Building Approach. John Wiley \& Sons Inc.

Siddiqi, K.O., 2011. Interrelations between service quality attributes, customer satisfaction and customer loyalty in the retail banking sector in Bangladesh. International Journal of Business and Management, 6(3), p.12.

Wakefield, K.L. and Blodgett, J.G., 1999. Customer response to intangible and tangible service factors. Psychology \& Marketing, 16(1), pp.51-68.

\section{APPENDICES}

\section{Sample Questionnaire}

Customer Perception on Bank Service Quality: A Comparative Study between Conventional Commercial Banks and Islamic Banks in Bangladesh

Name:

Gender: $\square$ Male $\square$ Female

Age group: $\square$ 18-30 $\square 31-45 \square$ Above 45 years

Occupation:

Bank Name:

Please select one response from each of the following items.

$\mathrm{SD}=$ Strongly Disagree, $\mathrm{D}=$ Disagree, $\mathrm{N}=$ No opinion, $\mathrm{A}=$ Agree, $\mathrm{SA}=$ Strongly Agree

\begin{tabular}{|c|c|c|c|c|c|c|}
\hline Dimensions & Independent Variables & SD & D & $\mathbf{N}$ & $\mathbf{A}$ & SA \\
\hline \multirow[t]{3}{*}{ Tangibility } & 1. The bank has all the necessary modern equipment & SD & D & $\mathbf{N}$ & $\mathbf{A}$ & SA \\
\hline & $\begin{array}{l}\text { 2. Employees are suitably dressed and have neat } \\
\text { and clean appearance }\end{array}$ & SD & D & $\mathbf{N}$ & $\bar{A}$ & SA \\
\hline & $\begin{array}{l}\text { 3. Branches have proper waiting and sitting } \\
\text { arrangements }\end{array}$ & SD & D & $\mathbf{N}$ & $\mathbf{A}$ & SA \\
\hline \multirow[t]{3}{*}{ Reliability } & $\begin{array}{l}\text { 1. The bank provides all the services within the } \\
\text { promised deadlines }\end{array}$ & SD & $\mathbf{D}$ & $\mathbf{N}$ & $\mathbf{A}$ & SA \\
\hline & The bank keeps its records accurately & SD & $\mathbf{D}$ & $\mathbf{N}$ & $\mathbf{A}$ & SA \\
\hline & 3. I feel safe with all my transactions in the bank & SD & D & $\mathbf{N}$ & $\mathbf{A}$ & SA \\
\hline
\end{tabular}




\begin{tabular}{|c|c|c|c|c|c|c|}
\hline \multirow[t]{3}{*}{$\begin{array}{l}\text { Responsive } \\
\text { ness }\end{array}$} & $\begin{array}{l}\text { 1. The bank provides fast and efficient counter } \\
\text { services }\end{array}$ & SD & $\mathbf{D}$ & $\mathbf{N}$ & $\mathbf{A}$ & SA \\
\hline & $\begin{array}{l}\text { 2. Whenever I face any sort of banking problems, } \\
\text { the employee help me in solving the problems }\end{array}$ & SD & $\mathbf{D}$ & $\mathbf{N}$ & $\mathbf{A}$ & SA \\
\hline & $\begin{array}{l}\text { 3. The bank operates a regular and effective } \\
\text { complaint handling process }\end{array}$ & SD & $\mathbf{D}$ & $\mathbf{N}$ & $\mathbf{A}$ & SA \\
\hline \multirow[t]{3}{*}{ Assurance } & $\begin{array}{l}\text { 1. the employee are efficient and fast in service } \\
\text { delivery }\end{array}$ & SD & $\mathbf{D}$ & $\mathbf{N}$ & $\mathbf{A}$ & SA \\
\hline & 2. Employees of bank are polite and helpful & SD & $\mathbf{D}$ & $\mathbf{N}$ & $\mathbf{A}$ & SA \\
\hline & $\begin{array}{l}\text { 3. Employees have strong knowledge to } \\
\text { answer enquiries about the offering and the } \\
\text { operations }\end{array}$ & SD & $\mathbf{D}$ & $\mathbf{N}$ & $\mathbf{A}$ & SA \\
\hline \multirow[t]{3}{*}{ Empathy } & $\begin{array}{l}\text { 1. The bank always informs me about new and } \\
\text { attractive offers }\end{array}$ & SD & $\mathbf{D}$ & $\mathbf{N}$ & $\mathbf{A}$ & SA \\
\hline & $\begin{array}{l}\text { 2. The banks provides convenient service } \\
\text { charges }\end{array}$ & SD & $\mathbf{D}$ & $\mathbf{N}$ & $\mathbf{A}$ & SA \\
\hline & $\begin{array}{l}\text { 3. Staffs have the enthusiasm to understand } \\
\text { customer needs }\end{array}$ & SD & $\mathbf{D}$ & $\mathbf{N}$ & $\mathbf{A}$ & SA \\
\hline \multirow[t]{3}{*}{ Technology } & $\begin{array}{l}\text { 1. Bank provides ATM service and the } \\
\text { machines are installed at proper locations }\end{array}$ & SD & $\mathbf{D}$ & $\mathbf{N}$ & $\mathbf{A}$ & SA \\
\hline & $\begin{array}{l}\text { 2. I have not had difficulties with bank cards } \\
\text { of this bank }\end{array}$ & SD & $\mathbf{D}$ & $\mathbf{N}$ & $\mathbf{A}$ & SA \\
\hline & 3. The bank offers internet banking services & SD & $\mathbf{D}$ & $\mathbf{N}$ & $\mathbf{A}$ & SA \\
\hline $\begin{array}{l}\text { Overall } \\
\text { Service }\end{array}$ & I am satisfied with their overall service quality & SD & $\mathbf{D}$ & $\mathbf{N}$ & $\mathbf{A}$ & SA \\
\hline
\end{tabular}

\section{Path Coefficient of Both Banks}

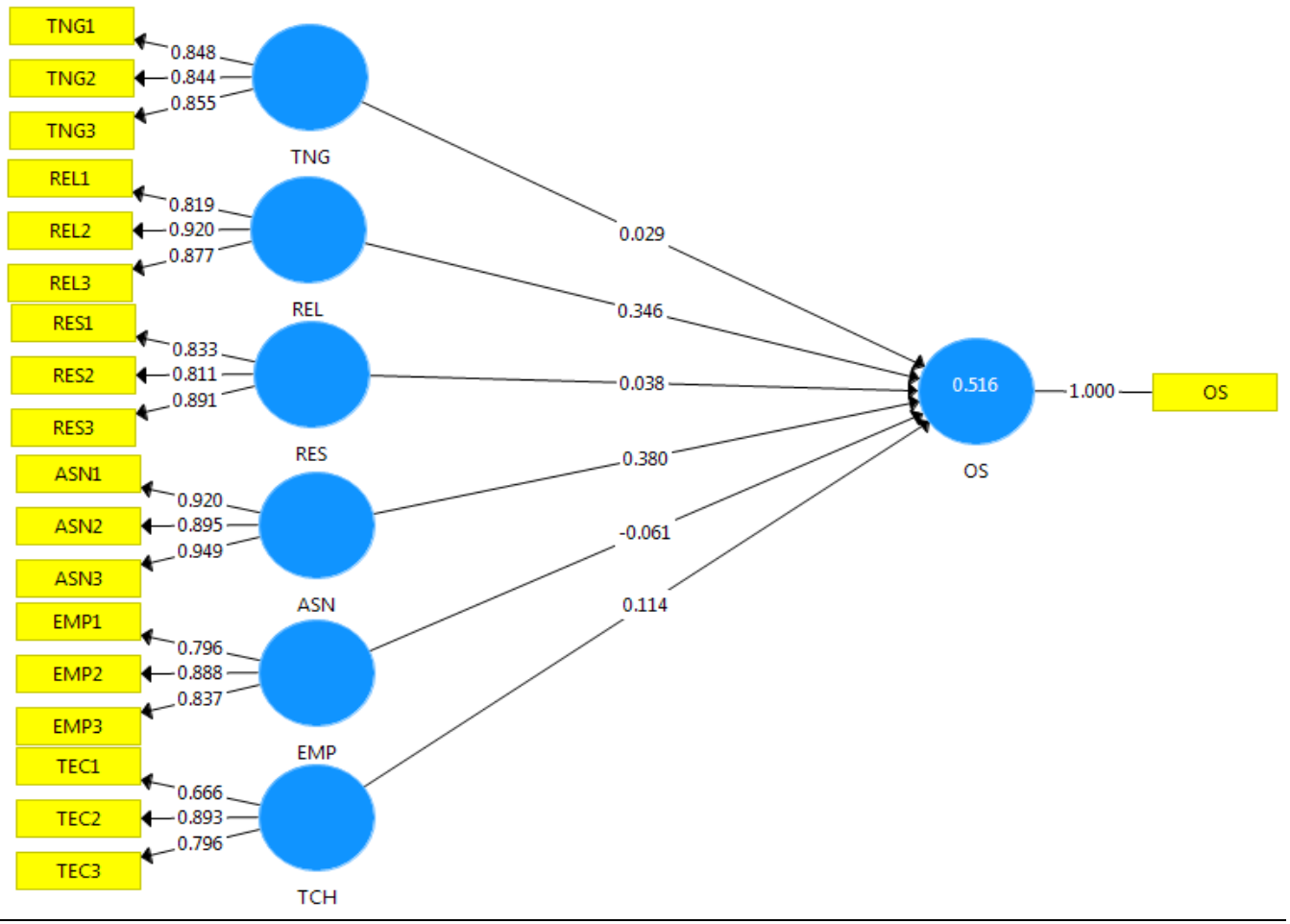




\section{Path Coefficient of Conventional Commercial Banks}

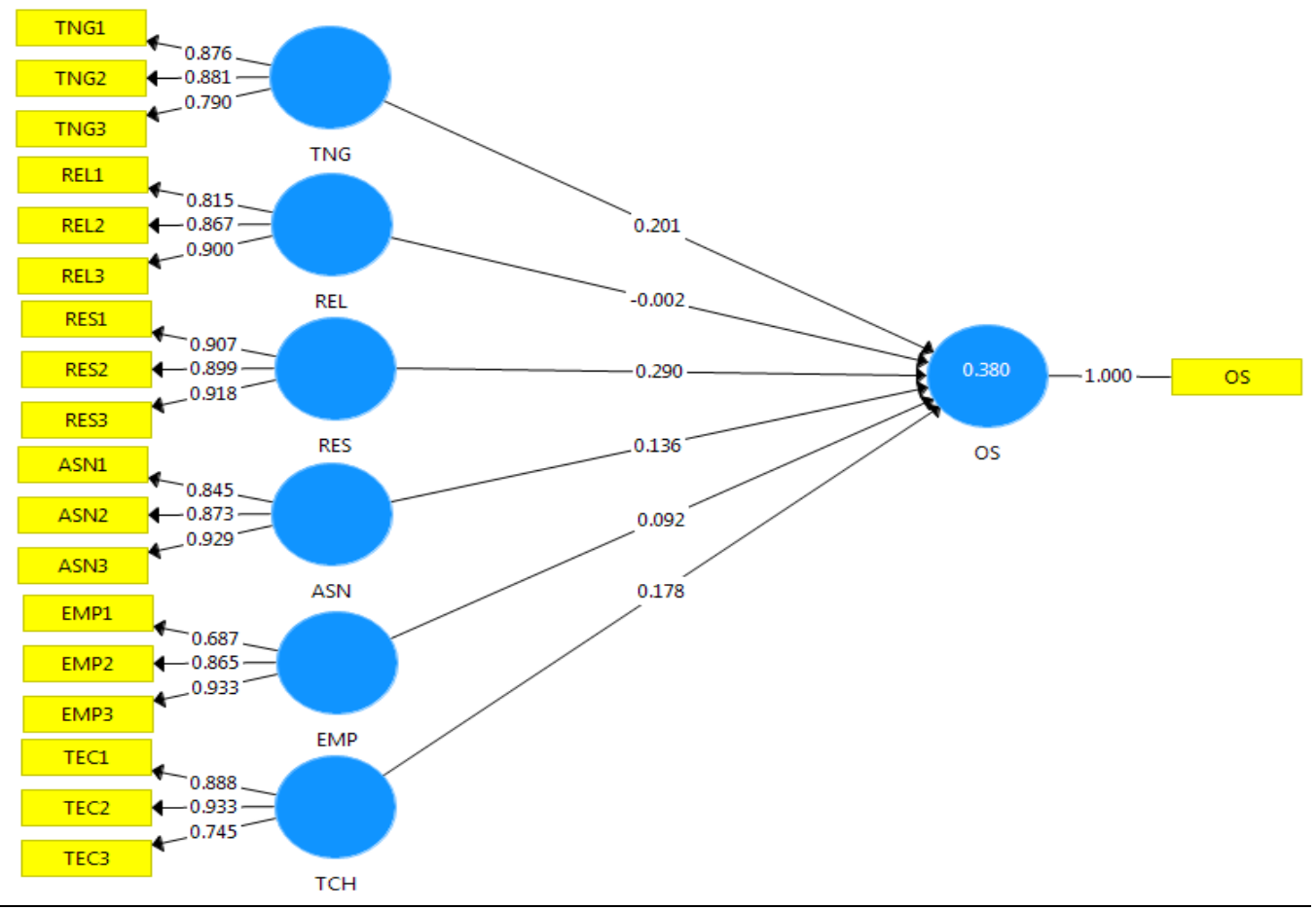

\section{Path Coefficient of Islamic Banks}

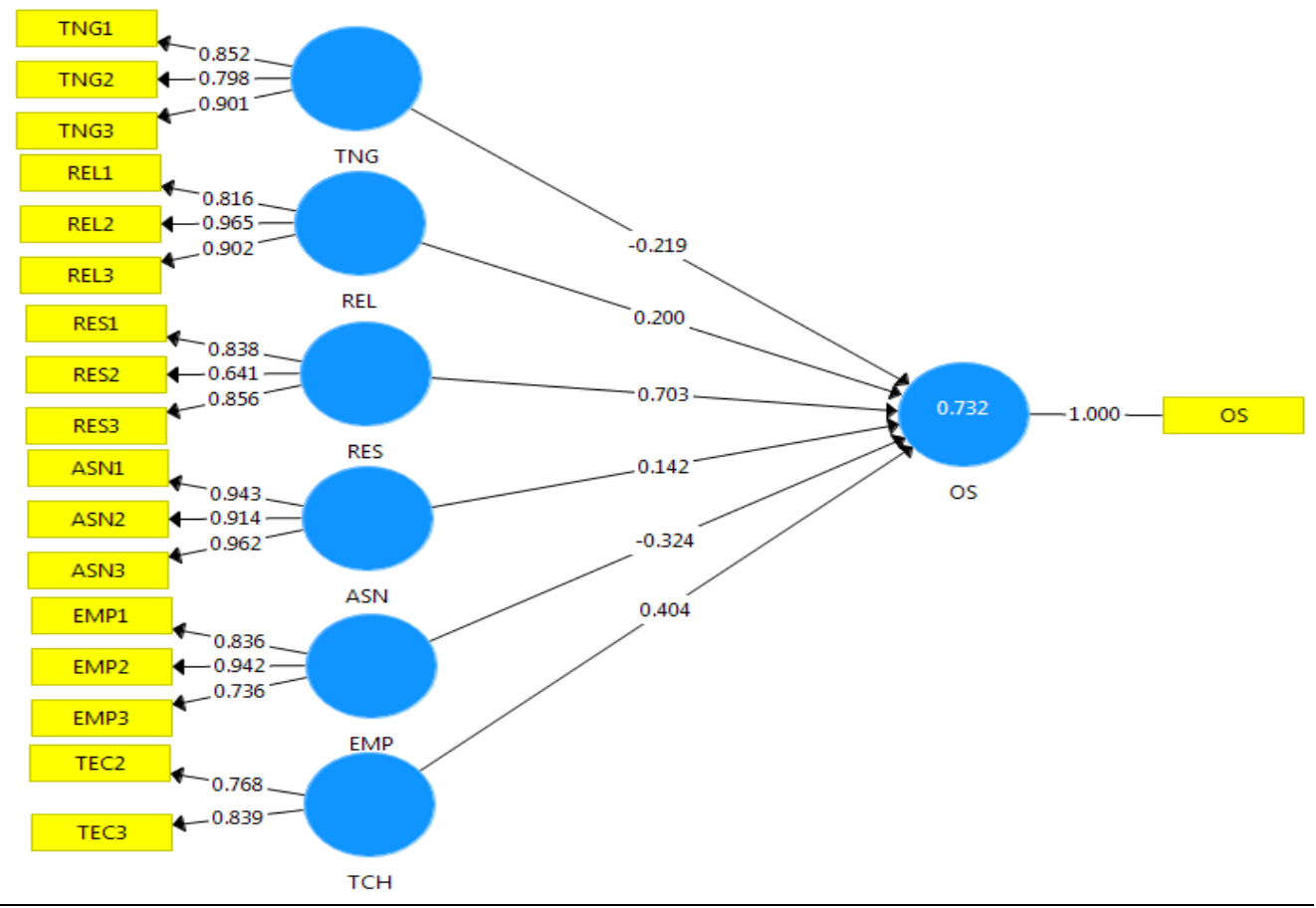

--0-- 